\title{
ETHNICITY-BASED RELIGIOSITY: Multi-Faceted Islam in Miami, USA, in the Age of War on Terrorism
}

\section{Ahmad Muttaqin}

Department of Comparative Religion, Faculty of Ushuluddin, Sunan Kalijaga State Islamic University Yogyakarta

\section{Syamsul Ma'arif}

Department of Religious Studies, Ariqona State University, USA

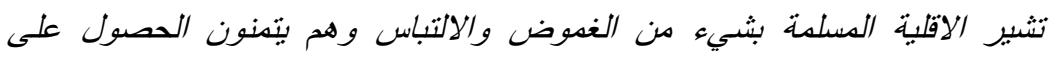

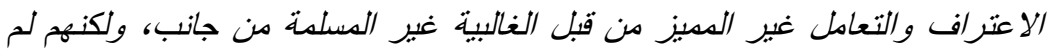

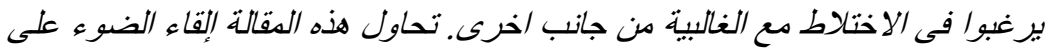

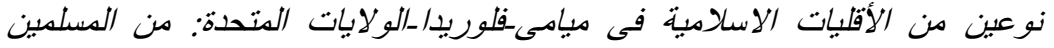

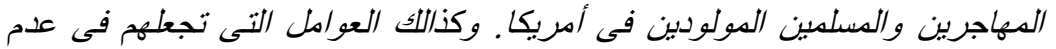

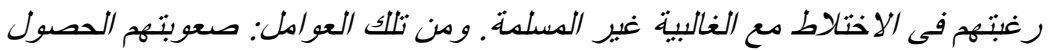

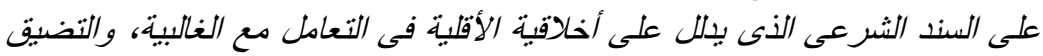

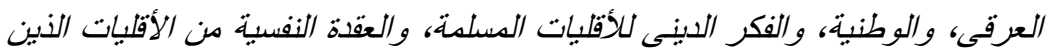

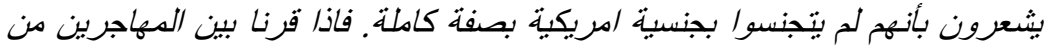

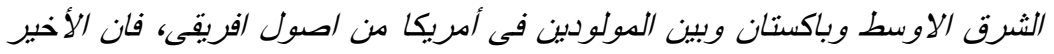

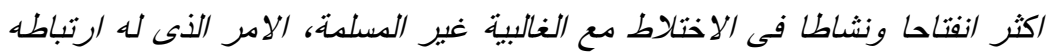

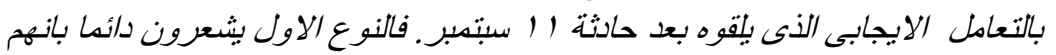

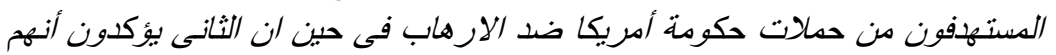

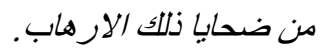

\section{Abstrak}

Minoritas Muslim seringkali menunjukean perilaku yang ambigu. Satu sisi mereka mendambakan pengakuan dan perlakukan yang tidak. 
diskriminatif dari kalangan mayoritas-non Muslim, namun di sisi lain ada "keengganan" untuk berbaur dengan kelompok mayoritas. Tulisan ini menguraikan dua tipe minoritas Muslim di Miami, Florida, Amerika Serikat, Muslim imigran dan Muslim kelabiran Amerika, serta menjelaskan berbagai faktor keengganan mereka dalam berbaur dengan mayoritas non Muslim. Di antara faktor keengganan tersebut adalab kesulitan mereka mencari rujukan ajaran Islam yang melegitimitasi "etika proaktif" minoritas terhadap mayoritas, segmentasi etnis, kebangsaan dan faham keagamaan minoritas Muslim, serta beban psikis mereka yang merasa belum sepenubnya menjadi warga negara Amerika Serikat. Dibandingkan kaum Muslim imigran yang sebagian besar berasal dari Timur Tengah dan Pakistan, kaum Muslim keturunan Afrika yang labir di Amerika cenderung lebih terbuka dan aktif berbaur dengan kelompok mayoritas non-Muslim. Sikap ini ternyata berkorelasi positif dengan perlakukan yang mereka peroleh pasca tragedy 9/11. Kelompok pertama merasa selalu menjadi target operasi anti teror pemerintah Amerika, sedangkan kelompok kedua justru menekankan bahwa mereka adalah korban dari terorisme tersebut.

Keywords: Muslims Minority, Immigrant Muslim, American-Born Muslim

\section{A. Introduction}

Muslims, and Islam itself, in America present a plural and diverse face in terms of ethnicity, nationality, and Islamic school of thought. Describing the plurality and diversity of Islam in the USA, Zahid H. Bukhari et.al say, "it is only in the North American experience that one can find a white American Muslim standing in prayer next to an Indonesian Muslim, a Palestinian Muslim next to a Pakistani, an African-American next to a Senegambian or a Syrian, a Lebanese next to a Bosnian, a Trinidadian Muslim next to an Indian or Egyptian Muslim". ${ }^{1}$ This phenomenon is also true of Muslims in Miami, Florida.

${ }^{1}$ Zahid H. Bukhari, et.al, (eds), Muslims' Place in the American Public Square: Hope, Fears, and Aspirations (Lanham, MD: Rowman and Littlefield Publishers, Inc, 2004), p. $\mathrm{xv}$. 
Muslims from around the world come to Miami to study, work, or vacation; they are present in all the mosques of Miami, regardless of who administers the mosque.

The diversity and plurality of Muslims in Miami has led Islam to be expressed by Muslims in a variety of ways. Unfortunately, most western media, and consequently most of the American people, tend to reduce Islam to a single "countenance," and their view of it is a negative one. Such a depiction of Islam is understandable, especially after the 9/11 tragedy, because Islam and Muslims are viewed as a dangerous "foe" trying to smash Western culture and values. Moreover, the relationship between Islam and the West is mostly seen as a tense, oppositional relationship such that there can be no real compromise between Islam and the West. Such a paradigm clearly ignores the diversity and plurality of Muslims. This paper, therefore, will address the various voices of Muslims in Miami, Florida in public sphere, including the problems encountered and how Miami Muslims have overcome those difficulties. The description will illustrate the variety of voices within Islam in the USA based on ethnicity, nationality, and Islamic school of thought. The field data used in this paper is based on the 2004 Harvard Plusummer research done in Miami, Florida, the USA. ${ }^{2}$

\section{B. Searching for the Religious Guidance}

There are about 12,000 - 15,000 Muslims attending ten mosques for $\bar{T} d$ prayers among the 2,345,932 people of Miami Dade County. Compared to Christians, Muslims are obviously a minority. As a minority group, Muslims have encountered problems with others in their community who are in the majority. These problems are caused not only by external aspects such as the common hegemonic trend of majority cultures, but also by an internal aspect from the Islamic community itself.

Many American Muslims face a significant crisis, as Taha Jabir al-Alwany contends, with regard to their religious teachings. Al-Alwany

2 The writers would like to thank to Harvard Pluralism Project at Harvard University, for sponsoring the research. 
explains that the American Muslims have difficulties finding religious guidance about how to interact with the majority. The reason is that the American Muslims, as a minority, live in a situation that is radically different from the locus and tempus of the time of the prophet and even of Muslim societies in Muslim countries of the contemporary era. This means that the legal schools of Islam and the interpretation of the Quran and the Prophet tradition which were produced in the past and in the context of Muslims as the majority no longer fit the American Muslim situation. Therefore, according to Al-Alwany, Muslims in America need "a new figh for minorities. Their situation would be better if they could have an adequate methodology in order to understand and develop a "new approach that combines theology, ethics, and laws into a coherent structure capable of meeting the demands of modern times". 3

In addition to the concern about inadequate religious teaching, as a consequence of their background diversities, American Muslims are also divided into many groups and organizations. It is true that most mosques state they are open to and welcome any Muslims regardless of their ethnicity or schools of religious thought. However, there are many mosques that are dominated by certain ethnicity or schools of thought. The domination of certain ethnicity or schools of thought in Muslim communities can be seen either from their board members who maintain the mosques/Islamic Centres or from a plurality of members from a single ethnicity in a mosque. Although there has never been any significant conflict as a result of domination by certain groups, some people state that sometimes they feel alienated when they come to a mosque which is dominated by another group. ${ }^{4}$ Such a situation often leads them to go to a mosque which is further from his/her home, but one in which se/he would feel more comfortable, rather than to a closer mosque which is dominated by a different group from their own. In Miami, a good example of this situation is as stated

${ }^{3}$ Taha Jabir al-Alwany, "Toward a Fiqh for Minorities: Some Reflections", in Zahid H. Bukhari, et al. (eds.), Muslims' Place, p. 3-37.

${ }^{4}$ Aminah Beverly McCloud, "Conceptual Discourse: Living as Muslim in a Pluralistic Society”, in Zahid H. Bukhari, et al. (eds.), Muslims' Place, pp. 73-3. 
by a Kuwaiti-friend of the writers during the ${ }^{\bar{T}} d d$ al-A $A \underline{a} \bar{a}$ Festival. When he picked us up from our apartment and drove us to a certain mosque, he said, "Brother! Actually there is a mosque closer to our apartment, but I do not like to go to that mosque which is dominated by Pakistanis. Therefore, we are going to a mosque which is a little further."

Some American Muslims still have difficulties enjoying participation in the public sphere in accordance with the norms of American public life. Regarding this, there are different attitudes between immigrant Muslims and American-born Muslims. Generally speaking, the newcomers, immigrant Muslims in America, tend to be reluctant to participate in the American public sphere compared to American-born Muslims, who are primarily African-Americans. According to McCloud, the immigrant Muslims usually are still greatly involved with the political and cultural problems of their countries of origin; though they take full advantage of the educational opportunities of the United States, they are still preoccupied with the idea of changing things back home. In addition, immigrant Muslims also lack adequate understanding of the culture and politics in their American communities as well as of American social problems. ${ }^{5}$

Unlike immigrant Muslims, African-American Muslims are already deeply involved in American daily public life. They have a more advantageous position as American "citizens" than the immigrants. Their first African settlement in the USA occurred five centuries ago during slavery, significant numbers of slaves in America had been Muslims in Africa. Especially since the civil rights era AfricanAmericans, including Muslims, have been justifiably proud of being Americans and having contributed to American culture and civilization. ${ }^{6}$ In the case of Muslims in Miami, the African-American Muslims seem to be more readily accepting of Muslim plurality and involved in the American public sphere than the immigrants. For example, both students and the teachers in the Clara Muhammad [elementary] Schools at the Masjid al-Ansar and Masjid Ibrahim, which

${ }^{5}$ Ibid., pp. 76-77.

${ }^{6}$ Zafar Ishaq Anshari, "Islam among African Americans; an Overview", in Zahid H. Bukhari, et al. (eds.), Muslims’ Place, p. 265. 
are run by African-American Muslims, include not only Muslims but also non-Muslims. Such a phenomenon is rare if it exists at all in Islamic Schools managed by immigrant Muslim groups. Immigrant Muslims often withdraw their children from public schools and bring them to their own in order to have them socialized exclusively within their own religio-ethnic heritage.

The situations described above clearly indicate that Muslims in America still face a lot of significant problems or crises around issues of value, identity, and ambiguity regarding participation in the American public sphere. ${ }^{7}$ The crisis of value relates to the "hesitation" of Islamic communities to be deeply involved in the economic, educational, and social system of America. Miami Muslims are engaged in attempts to build Islamic Schools, to establish haläl grocery stores, and to avoid credit from conventional banks in favour of interest-free Islamic banking. The crisis of identity causes them to be "picky" in terms of which group they will associate with. A good example of such pickiness is a student from Pakistan who reflects salafy thought, who prefers going to a farther mosque for Friday prayer rather than to the closer one that is seen to follow a different school of thought. The same hesitation over inclusive participation is reflected in decisions about political participation and community life. Specific situations faced by the Muslim community in Miami will be described further in the coming sections.

Most Islamic communities have already realized the problems mentioned above. Some of them even have systematic programs to bridge the gap between Islamic values and American culture. For example, some Muslim immigrants acknowledge that they live in a plural community, which they may or may not be accustomed to, but here they are a minority within that pluralism. This situation leads them to consider that inter-religious and intercultural dialogue is important to building mutual understanding. Therefore, most Islamic Centres in America, if not institutionally at least in the person of the

${ }^{7}$ Ali A. Marzui, "Muslim between the Jewish Example and the Black Experience: American Policy Implications," in Zahid H. Bukhari, et al. (eds.), Muslims' Place, pp. 117-144. 
leader of the Centre, engage in inter-religious dialogue activities. However, as a consequence of American Muslim diversity regarding school of thought, nationality and ethnic background, there are various opinions and attitudes toward inter-religious dialogue within the Muslim community. For example, compared to immigrant Muslims, AfricanAmerican Muslims are more active in inter-religious dialogue. The reason is that the latter group is more deeply involved in American public life than the former. Unlike African-American Muslims who are American-born and regard America as their home country, immigrant Muslims often see themselves for extended periods of time as guests in America. Other reasons that lead African Americans to actively support inter-religious dialogue were clearly explained by Warith Deen Mohammed, the leader of The Muslim American Society, generally also known as the Ministry of W. D. Muhammad: (1) most AfricanAmerican Muslims were once Christian, and (2) many of them still have Christian families, so they know more about Christianity. ${ }^{8}$

American Muslims participate in inter-religious dialogue for various reasons. Some of them are actively involved in the dialogue based on their understanding of Islamic values, whereas others participate in the dialogue in order "to form political connections." Still others of them participate in inter-religious dialogue in light of da'wa (Islamic propagation) whereas the others do it in the spirit of bridging the gap between Muslims communities and their counterparts. ${ }^{9}$

The inter-religious dialogue activities of American-Muslims are usually arranged between Muslims and Christians or sometimes also trialogue among the practitioners of the three Abrahamic religions, JewsChristians-Muslims. Rarely do Muslims have special programs of interreligious dialogue among American immigrants with religions such as Hinduism, Buddhism, Sikhism, Confucianism, or other non-Semitic religions.

In terms of Muslim-Christian dialogue in the United States, Smith notes that there are seven models: (1) the confrontation/debate model;

${ }^{8}$ Jane I. Smith, "Muslim as Partners in Interfaith Encounter", in Zahid H. Bukhari, et al. (eds.), Muslims' Place, pp. 165-200.

${ }^{9}$ Ibid., p. 173. 
(2) dialogue as information-sharing model; (3) the theological exchange model; (4) the ethical exchange model; (5) the "dialogue to come closer" model; (6) the spirituality and moral healing model; and (7) the cooperative model for addressing pragmatic concerns (2004: 167171). ${ }^{10}$ Among the seven models stated above, most American Muslims regard model number 2, the information-sharing model, as the best way for Muslims to be involved. For most Muslims in America, mainly immigrant Muslims, the other models do not meet what Muslims need. They emphasize that some of the models, especially models number 3 and 6, could endanger Muslims who might not have enough education and training to do such dialogue without endangering their faith. This does not mean, however, that there are no Muslims participating in the other models. A small number of Muslims, in fact, believe that dialogue should be done in greater depth involving pragmatic, spirituality, ethical exchange, or even the theological model, rather than just the information-sharing model. It is worth noting also that the participation of American Muslims in inter-religious dialogue with Christians tends to be "passive" participation. Most of the events of dialogue are initiated and invited by the Christian community. ${ }^{11}$

The diversity of Muslims in America and their various forms of expression also affected their response to the $9 / 11$ tragedy. The consequences that American Muslims faced and the response they voiced were also determined by their backgrounds. The following chapter focuses on the views and problems of Miami Muslims' communities in the age of war on terrorism and strategies they have used to overcome the problems.

\section{Muslim in Miami: Various Background, Various Expression}

After the 9/11 tragedy, many Muslims and Islamic Centres in the United States were under threat, ranging from being the target of suspicion to being the victim of vandalism. Such a situation also occurred in Miami. The Miami Herald (September 16, 2001) reported that some Muslim students in University of Miami said they were

\footnotetext{
${ }^{10}$ Ibid., pp. 167-171.

${ }^{11}$ Ibid., p. 174.
} 
verbally harassed on campus. CAIR Florida (2004) and the Miami Herald (May 15, 2004) reported that on Tuesday May 11, 2004, Masjid alIhsan was attacked, the front door and windows were broken, telephone and electrical lines were cut and the alarm system was destroyed. On Wednesday, May 12, 2004, a swastika and curse words were spraypainted at the Islamic School of Miami at 11699 SW 147th Ave. Both the mosques are included in this research. On Thursday, May 13, 2004 a note was found at the Darul Uloom Institute, an Islamic Centre at 7050 Pines Blvd. in Pembroke Pines. The note read, "Kill them all in the name of Allah."' Those incidents of vandalism and threats against the Muslim community, of course, created fear among Muslims in Miami. ${ }^{12}$

In general, the Muslim communities that were observed in this research could be broken down into two categories. The first is Muslim immigrant communities that are primarily found in Masjid Miami, Masjid Miami Garden, Masjid an-Noor, Masjid al-Ihsan, Masjid al Fayza, Masjid Shamsuddin and Masjid al-Mukmin. The second category is Americanborn Muslim communities, predominately Afro-American, and they are dominant in Masjid Al-Ansar and Masjid Ibrahim.

These two kinds of Muslim communities have varying responses and attitudes regarding the $9 / 11$ tragedy. For example, the first group responded to the tragedy more seriously than the later. Although most of them stated that they did not have significant personal problems after $9 / 11$ and they did not increase or decrease their programming, such as religious activities in their mosques, in response to $9 / 11$, they did get involved in public affairs in an effort to respond to stereotypes and fears that Americans have about Islam and/or to clarify Islam and Muslims. They seem to do that because they feel responsible for responding to the stigma that $9 / 11$ created for Muslims. It was, for instance, stated by the Imam of Masjid Shamsuddin that 9/11 created a certain stereotype or stigma which connects Muslims and terrorism

${ }^{12}$ Hillary Wash, "Islamic Leader Get FBI Help", Miami Herald, 2004, http:/ / www.miami.com/mld/miamiherald/news/local/states/florida/counties/broward_ county/8671588.htm; retrieved on August 10 ${ }^{\text {th }}, 2004$. See also: "Two Miami Mosques Vandalized, One Threated", CAIR-Florida, 2004, http://www.cair-florida.org/ ViewArticle.asp?Code $=$ CM\&ArticleID=230); retrieved on August 9 ${ }^{\text {th }}, 2004$. 
in many people's minds. Although most Muslims in the community were never physically harassed, most felt psychologically bothered by the negative images. This mosque did not organize a program of response but it did became more open and progressive, welcoming non-Muslims who want to know or learn about Islam by providing free Islamic books supplied by AMANA (American Muslim Association of North America), an organization run by mostly Middle Eastern Muslims, which has served Muslim communities in the United States since 1992 and has three branch offices, in Puerto Rice, Atlanta, and Pennsylvania.

Muslims in this first category confess that the $9 / 11$ tragedy was a tragedy for Muslims as well. While they insist that Muslims are not the cause of the tragedy, because those who committed the attacks were not true Muslims, they frequently feel frustrated by the media treatment of Islam. In their opinion, the media implies that all Muslims should be responsible for $9 / 11$. And the media has served to strengthen the link between all Muslims and the tragedy. As a result, people assume that Muslims are dangerous people. However, for the Imam of Masjid Shamsuddin, people who have such assumptions do not understand Islam and Muslims. AMANA, through various programs and the director's involvement in inter-religious relationships, has continued describing Islam as a peaceful religion and Muslims as peaceful people, not terrorists. Masjid an-Noor invited non-Muslims to the mosque and explained to them that they did not take any part in attacks and they actively promote peace in society. Most Imams welcome and appreciate invitations by Christians and Jews for dialogue. In their speeches, whether in churches or synagogues, the Imams emphasized that Islam teaches Muslims to support peace.

The immigrant Muslim communities responded very differently to $9 / 11$ than did the American-born Muslim communities dominated by African-Americans. The American-born Muslims did not need to justify their lack of role in the tragedy. They did not expect people to see them as the cause of the tragedy, and they rejected any form of blame, both because their role and function in American civil society has been established for a long time before the 9/11 tragedy, but also because African-American organizations, especially religious 
organizations, have a reputation earned in the civil rights movement for nonviolence even under severe provocation.

In fact, some people did come to these African-American Muslim communities and ask about the tragedy, but the communities simply responded that while those who were behind the attack might be Muslims, the attackers' understanding of Islam is surely different from that of these communities. For these communities, it makes no sense to commit such an attack and at the same time claim to be Muslims.

\section{Exploring the Problems}

\section{Crime by Association and Disassociation of Muslims}

The 9/11 tragedy is often assumed to be a tragedy caused by Islam. At least that is what people and the media generally report and Muslims have been made to feel. Internationally and nationally Muslims are bothered by people's assumption that Islam is a violent religion. Ignoring even the Muslims who were killed by these attacks on the U.S., many other Muslims have suffered as a result of the 9/11 tragedy. For example, some Muslims who were travelling in the U.S. at the time and since have been treated poorly by police and airport personnel. Some Muslim women were asked to take off their hijäbs or jilbābs (veils) by airport personnel.

This discrimination happens because people tend to approach the 9/11 tragedy in terms of "a crime by association," as one Imam suggested. In the U.S. such a policy by police associations is called $\mathrm{racial} /$ ethnic/ religious profiling. This means that because it is assumed that those who committed the 9/11 attack were Muslims, all those who claim to be Muslims are under suspicion as being responsible for the tragedy. They were judged and blamed not because of anything that they had done but because of who they were. This is what one informant from the Masjid al Ihsan was most concerned about. For him, logically, someone should only be judged because of what s/he does, and not because of who s/he is. Because of such profiling, or crime by association, some Muslims hide their identities or even "disassociate" from the Muslim community. For example, some Muslims shaved their beards, other Muslims changed their names, and some 
Muslim women removed their jilbāb (veils). Some Muslims did not want to be a part of any Islamic activity.

Because of the tendency to become "criminals by association," some Muslims took responsibility for responding to the suspicions and disassociated themselves from other Muslims, specifically from those who had claimed to be Muslims and yet committed the 9/11 attack. Muslims affiliated to the Masjid al-Muhmin, for instance, believe that those who attacked on September $11^{\text {th }}$ were not true Muslims.

In the same manner, an informant from the Masjid al Fayza insisted that Islam is not determined by the beliefs or actions of individuals. Islam is based on the shari'a (the law of Islam): what the Quran says and what the prophet Muhammad told Muslims to do. As an individual, each person can do as s/he chooses, even those actions which are against shari'a. What an individual does is his or her choice, but it is not the case that everything an individual does is necessarily Islamic. The Imam of Masjid al Fayza said, "What happened on 9/11 is that we are not a part of that. We, Muslims in this community, did not take part in or even support the attack." The Imam also emphasized that the public must learn to differentiate between Muslims and Islam. Any person can be a Muslim, but s/he might still do the wrong thing or break the law of Islam. Islam is the basis of what individual Muslims should do. Because Islam means peace and teaches peace, Muslims should support peace.

Another explanation is also presented by Muslims affiliated to the Masjid Miami Garden. For them, the tragedy of 9/11 hurt all people. It was against humanity. It was against the beliefs of all religions because the people who died at that time were Christians, Jews, and followers of other religions, including Muslims. Therefore, those who committed this attack did not respect human life and religious ideas; there is no way to religiously justify the attack.

Thus, very generally, there are two kinds of Muslim disassociation found in the Muslim communities of Miami. First, some Muslims avoid being identified with or taking part in any Islamic affiliation. They hide their identity as Muslims. This is not a recognition that those who committed on September $11^{\text {th }}$ attack were true Muslims, but is an inability or unwillingness to deal with the majority's judgment of Islam 
as a religion supporting terrorism. Second, some Muslims stand against the stigma by insisting that those who claim to be Muslims and yet commit violent attacks, especially those who committed the 9/11 attack, are not true Muslims. Even if they believed they were Muslims, they surely presented Islam incorrectly

\section{Fear and Uncertainty}

Based on news reported by the media as stated above, there were both physical and psychological harassment of Muslims following 9/11. Interestingly, most Muslims in Miami interviewed in this research, did not speak up. They even said, "there was not any physical attack from anywhere." Perhaps there are several reasons why they did not speak up. One of them might be because they try to forget that memory because they are in the process of recovery. A second reason might have been that they did not want to call more attention to themselves. A third reason could have been fear of persecution.

Some local Muslims were scared and did not know what to do. Some Muslims came to see Imams and asked them whether they should come to a mosque or not. The Imam of the Masjid Miami Garden, for example, encouraged Muslims to be patient and come to the mosque even more frequently for support. According to the Imam, it was the time to show people that what they are doing in the mosque is to call people to peace and respect for others.

Some Muslim women also came to the Imam at the Masjid Miami Garden and asked if they should take off their jilbab. "No" was the answer of the Imam, but he told them to make efforts to show people that they are peaceful people. They should initiate conversation with people. The women came back to the Imam later on and said that at first when they responded to questions or initiated conversation, often regarding the veil or Islam, people looked at them strangely, but when they started talking openly and kindly, people were also kind and nice to them.

The second year after the 9/11, the Masjid Miami Garden issued an invitation to a meeting to all local Imams/ leaders of communities and also to non-Muslims. Most of the people who came were Muslims. At that meeting the leaders declared that they, Muslims, are part of 
this state, and part of this country. Therefore, whatever is good for Muslims as citizens, has to be good for the country, and whatever is bad for this country must be bad for Muslims. Consequently, Muslims have to have positive civic attitudes and contribute to this country. The Imam stated, "We are blessed to be here in the U.S. This is the place you can practice your religion freely."

Unlike most other Muslim communities, the Muslim community affiliated to the Masjid al-Muhmin had problems after 9/11. Their bank account (the mosque account) was frozen without notice. They only learned about this when they came to the bank to make a transaction and the bankers told them that their account was frozen because of a police investigation. It was frozen for a month and then released. Some of them got calls from unidentified people who said, "You are a Muslim, you are a terrorist."

Several weeks after 9/11, some strangers came to the Masjid alMuhmin for Friday prayer. This happened at the Masjid Miami as well. Muslims suspected that these strangers were spies or FBI agents, because they did not talk to any one, and they did not make return visits. These events were experienced as threatening. As a result, the Imam of the Masjid al-Muhmin was reminded by some members not to say anything about politics in his sermons. One time, the Imam was asked to go see policemen in order to discuss something, but the Imam ignored the request. For the Imam, it was fine to talk to the police if they came to him with questions, but he would not seek them out.

This situation created fear and uncertainty for some Muslims in this community and in other local Muslim communities. They did not know what to do, because while they knew that they were not part of the attack, they felt monitored and distrusted, labelled by other people as violent.

\section{E. After the Tragedy: Rearranging Programs and Intensifying Interreligious Dialogue}

In fact, most Islamic centers or mosques in Miami were not so affected by the $9 / 11$ tragedy as to feel pressured into changing or extending their programs. They did create some programs after 9/11 but not in direct response to $9 / 11$ itself. Those programs organized 
after the 9/11 developed because individual mosques found the resources to support them and because the programs were contextually needed. For example, the Masjid al-Ihsan has a program created after $9 / 11$ to help the needy, regardless of their religious beliefs. They began this program because they felt responsible for helping the needy and they were able to begin it at that time. The community also more openly welcomed people who are interested in Islam. This mosque has recently provided a lot of Islamic books and given them away to people free. Those books are in many languages, especially in Spanish, in order to respond to local patterns of need. In one way this program seems to be a response to $9 / 11$, because after $9 / 11$ many more people in Miami, as in the U.S. in general, became interested in learning about Islam.

AMANA also reflects similar attitudes. All programs that AMANA organizes right now are basically continuations of those which were established before 9/11. AMANA never intended to respond the tragedy of $9 / 11$. For AMANA, there are many things happening throughout the world as bad as or even worse than 9/11. What AMANA is doing is the Islamic duty to deliver and implement the messages of God. God requires believers to create peace, help others, and take care of each other no matter what the other believes. During his lifetime, the prophet Muhammad helped a Jew who was not even kind to him.

However, both the involvement of AMANA's director in some inter-faith and public organizations and the programs of AMANA themselves illustrate the intensification of inter-religious dialogue. This involvement is based on the mission of AMANA itself which is to strive to clarify the truth about Islam and Muslims. AMANA has continued to inform people in various ways, such as speeches, distributing Islamic books, through the internet and so forth. Their goal is to demonstrate that Islam is a very peaceful religion and to clarify what real Muslim communities are doing in this country.

Although the Masjid al-Fayza and the Masjid al-Muhmin did not have any programs responding to $9 / 11$, some Muslims associated with those two mosques realized the importance of being involved in interreligious dialogue. The Imam of the Masjid al-Fayza, for instance, explained that the community in which they live is a melting pot community. People who are culturally, ideologically, and even 
nationally different live side by side. So, dialogue is very important. In fact, the Imam himself has frequently been involved in some interreligious dialogue, especially when invited by Jewish or Christian people who need to know about Islam. Another reason that the Imam gives for his involvement in inter-religious dialogue is to clarify misunderstandings that many people have about Islam.

The Imam of the Masjid Al-Muhmin also was frequently invited to give speeches in churches and he always tried to convince people that Islam does not support terrorism, that it strongly forbids terrorism and killing people. For Islam, killing one innocent person is like killing all human beings. ${ }^{13}$ Therefore, those who attacked on September $11^{\text {th }}$ were not true Muslims. Islam means to surrender to the will of Almighty Allah in promoting peace in this world. The Imam also explained that the term "jihād" is misinterpreted by people. Jihād has two meanings: the first is jihäd nafs, which means to fight against yourself, your selfish desires, and the second one is jihäd fi sabilil-Lăh, which means to fight in a defensive war if somebody attacks you or stops you from practising your religion. ${ }^{14}$

For Muslims affiliated to the Masjid an-Noor, the 9/11 tragedy did not significantly affect them. They recognized that some Muslims were stigmatized by the tragedy, so they often invited some Muslim scholars from CAIR (Center for American-Islamic Relations) to give lectures for members about how to deal with the issues of $9 / 11$, including how to support each other in the face of discrimination from the wider community. How to deal with non-Muslims in general was also discussed. In addition, since they realized that media treatment of Islam was biased after 9/11, they invited non-Muslims and explained to them that Islam is a peaceful religion. Consequently, this community

${ }^{13}$ This statement refers to the Quran, V: 32.

${ }^{14}$ This Imam is referring to a hadith that tells of a time when the Prophet Muhammad and his companions returned from a battle. At that time, the Prophet said, "we are returning from a small battle and going towards a greater battle: a battle against our own desire.” See Abū Hamìd al-Gazāly, Ibyā' 'Ulüm al-Dìn, http:// www.alwaraq.com/index5.htm?c=http://www.alwaraq.com/cgibin/doccgi.exe/book; retrieved on August 9th, 2004. 
got some support from some Jewish rabbis and Christian priests who came to the mosque after $9 / 11$.

\section{F. Conclusion: the "Fruits" of the Problems}

For Muslims in Miami, 9/11 has created a difficult situation in some ways, but in other ways, it has created some advantages as well. These advantages in Islam are called the "fruit" of the problem. In Islamic teaching, "after hardship is joy." There are at least three positive impacts of $9 / 11$.

First, although in the beginning some Muslims disassociated with the Islamic community by hiding their identities, later many Muslims are reported to have become more intense in practicing Islam. Many come to a mosque more regularly and are more supportive of many Islamic activities. They seem to have realized that Islam is a true guidance for their lives and Muslims are their partners in social life.

Second, Islam has become more interesting to people. The Quran is one of the best-selling books in the U.A. for the last three years. This means that the message of God is spreading to people. It does not matter the reason people have for learning about Islam or reading the Quran. Perhaps, some people have certain 'dangerous' motives for studying Islam, but that is not of concern to Muslims. Anyone can study the Quran and decide whatever s/he wants. Also, after 9/11 a lot of people from many different cultures came to mosques and converted to Islam. Today, it is not difficult to find U.S.-born Americans in the mosques of Miami.

Third, Miami Muslims are since 9/11 more open and progressive about being involved in inter-faith relations. Muslims have established good relationships with non-Muslims. However, the model of interfaith dialogues needs improvement. In many meetings, Muslims just come and give speeches about Islam and Muslims and they do not learn about other beliefs.

In order to build a good relationship among followers of different religions in Miami, there must be an institution which organizes interreligious dialogue. In this space, all religious followers could come together, sit and stand equally, and talk and listen to each other. They could share what they believe and then they could understand each 
other. Such an institution does not now exist. Existing institutions for Christian-Jewish dialogue have not been expanded to include Muslims as equal discussion partners, though they have at times invited Muslim leaders to speak to Christian and Jewish leaders.

In light of ethnicity-based religiosity, it is clear that the African American Muslim are more ready to deal with the American public sphere than the immigrant Muslims. Seen from Kettani's perspective, the African American Muslim are an example of "the Abyssinian model" for Muslims minorities in a non-Muslims majorities where they actively engaged in American public sphere. Conversely, the Immigrant Muslims still reflect "the Makkah models," where "the Muslims minority subject to cruel and unrelenting pressure is constrained to opt for bijrah or belligerence and warfare." ${ }^{15}$ For this reason, the later group are tend to be reluctant and actively deal with the culture of non Muslim majorities.

${ }^{15}$ Syed Z. Abedin, "Foreword", in M. Ali Kettani (ed.), Muslim Minorities in the World Today (London \& New York: Mansell Publishing Limited, n.d.), p. xv. 


\section{BIBLIOGRAPHY}

Al-Ghazāil, Abū Hamid. "Ihyàà' 'Ulūm al-Din,” Http:/ / wmw.alwaraq.com/ index5. htm. Retrieved on August 9 ${ }^{\text {th }}, 2004$.

Al-Alwani, Taha Jabir, "Toward a Fiqh for Minorities: Some Reflections", in Zahid H. Bukhari, et al. (eds.), Muslims' Place in the American Public Square, Hope, Fears, and Aspirations, Lanham, MD: Rowman and Littlefield Publishers, Inc, 2004.

Hadad, Yvonne Y., "A Century of Islam in America." The Moslem World. Ocassional Paper No. 4. Wasington, DC: Islamic Affairs Programs The Middle East Institute, 1986.

Kettani M. Ali, (ed.), Muslim Minorities in the World Today. London \& New York: Mansell Publishing Limited, 2004.

McCloud, Aminah Beverly, "Conceptual Discourse: Living as Muslim in a Pluralistic Society", in Zahid H. Bukhari, et al. (eds.), Muslims' Place in the American Public Square, Hope, Fears, and Aspirations, Lanham, MD: Rowman and Littlefield Publishers, Inc., 2004.

Marzui, Ali A., "Muslim between the Jewish Example and the Black Experience: American Policy Implications," in Zahid H. Bukhari, et al. (eds.), Muslims' Place in the American Public Square, Hope, Fears, and Aspirations, Lanham, MD: Rowman and Littlefield Publishers, Inc., 2004.

Nimer, Muhamed, The North American Muslim Resource Guide, Muslim Community Life in the United States and Canada. New York: Routledge, 2002.

Smith, Jane I., "Muslim as Partners in Interfaith Encounter," in Zahid H. Bukhari, et al. (eds.), Muslims' Place in the American Public Square, Hope, Fears, and Aspirations, Lanham, MD: Rowman and Littlefield Publishers, Inc., 2004.

Anshari, Zafar Ishaq, "Islam among African Americans; an Overview," in Zahid H. Bukhari, et al. (eds.), Muslims' Place in the American Public Square, Hope, Fears, and Aspirations, Lanham, MD: Rowman and Littlefield Publishers, Inc., 2004. 
Ahmad Muttaqin and Syamsul Ma'arif

Wash, Hillary, "Islamic Leader Get FBI Help", Miami Herald http:// www.miami.com/mld/miamiherald/news/local/states/florida/counties/ broward_county/8671588.htm. Retrieved on August 10 $0^{\text {th }}, 2004$.

CAIR-Florida, Two Miami Mosques Vandalized, One Threated. http:// www.cair-florida.org/ViewArticle.asp?Code $=\mathrm{CM} \&$ ArticleID $=$ 230). Retrieved on August 9 $9^{\text {th }}, 2004$. 